\title{
Pelatihan Deteksi, Tatalaksana, Pencegahan Anemia Anak Usia Sekolah Di Madrasah Ibtidaiyah Fatthur Rahman Makassar
}

\author{
Irmayanti $^{*}$, Nurfachanti Fattah ${ }^{2}$, Nadila Raudhani ${ }^{2}$ \\ ${ }^{1}$ Departemen Ilmu Patologi Klinik, Fakultas Kedokteran, Universitas Muslim Indonesia \\ ${ }^{2}$ Departemen Parasitologi, Fakultas Kedokteran, Universitas Muslim Indonesia \\ *Email korespondensi: irmayantihaidir@gmail.com \\ Telp: +628114114933
}

\begin{abstract}
ABSTRAK
World Health Organization (WHO) dalam Worldwide Prevalence of Anemia melaporkan bahwa total keseluruhan penduduk dunia yang menderita anemia adalah 1,62 miliar orang dengan prevalensi pada anak sekolah dasar 25,4\% dan 305 juta anak sekolah di seluruh dunia menderita anemia. Laporan Riset kesehatan dasar (Riskesdas) tahun 2013 menunjukkan bahwa anemia defisiensi besi masih merupakan masalah kesehatan masyarakat Indonesia dengan prevalensi pada anak usia 5 - 12 tahun sebesar 29\% dan di Kota Makassar sebesar 37,6\%. Dampak anemia bagi siswa sekolah dasar adalah dapat menyebabkan gangguan tumbuh kembang fisik, rendahnya daya tahan terhadap penyakit, tingkat kecerdasan yang kurang dari seharusnya, prestasi belajar/kerja dan prestasi olahraga yang rendah. Selain itu, anemia pada anak akan berdampak pada menurunnya kemampuan dan konsentrasi belajar, mengganggu pertumbuhan baik sel tubuh maupun sel otak sehingga menimbulkan gejala muka tampak pucat, letih, lesu dan cepat lelah sehingga dapat menurunkan kebugaran dan prestasi belajar. Salah satu cara untuk memberantas anemia pada siswa sekolah dasar adalah dengan membiasakan anak- anak sarapan untuk menjaga kesehatan dan meningkatkan perilaku anak di sekolah.
\end{abstract}

Kata Kunci: Anemia; sarapan; anak usia sekolah

\begin{abstract}
The World Health Organization (WHO) in the Worldwide Prevalence of Anemia reports that the total world population suffering from anemia is 1.62 billion people with a prevalence of $25.4 \%$ in primary school children and 305 million school children worldwide suffering from anemia. The 2013 Basic Health Research Report (Riskesdas) shows that iron deficiency anemia is still a public health problem in Indonesia with a prevalence in children aged 5-12 years of 29\% and in Makassar City of 37.6\%. The impact of anemia for elementary school students is that it can cause physical growth and development disorders, low resistance to disease, lower intelligence levels than it should be, learning / work achievement and low sports performance. In addition, anemia in children will have an impact on decreasing learning ability and concentration, disrupting the growth of both body and brain cells, causing facial symptoms to appear pale, tired, lethargic and tired quickly so that it can reduce fitness and learning achievement. One of the ways to eradicate anemia in elementary school students is to familiarize children with breakfast to maintain health and improve children's behavior at school.
\end{abstract}

Keywords: Anemia; breakfast; school age children 


\section{PENDAHULUAN}

World Health Organization (WHO) dalam Worldwide Prevalence of Anemia melaporkan bahwa total keseluruhan penduduk dunia yang menderita anemia adalah 1,62 miliar orang dengan prevalensi pada anak sekolah dasar 25,4\% dan 305 juta anak sekolah di seluruh dunia

menderita anemia. ${ }^{1}$ Secara global prevalensi anemia pada anak usia sekolah menunjukkan angka yang tinggi yaitu 37\%, di Thailand sebanyak 13,4\% dan di India 85,5\%, sedangkan prevalensi anemia di kalangan anak-anak di Asia mencapai 58,4\%, angka ini lebih tinggi dari rata-rata di Afrika $(49,8 \%)$.

Anemia masih menjadi masalah kesehatan masyarakat di Indonesia. Berdasarkan tempat tinggal didapatkan bahwa anemia di pedesaan lebih tinggi dari pada perkotaan yaitu sebesar $22,8 \%$. Secara nasional prevalensi anemia pada anak balita sebesar 28,1\% dan anak 5-12 tahun 29\%. Hal ini menunjukkan angka tersebut mendekati masalah kesehatan masyarakat berat (severe public health problem) dengan batas prevalensi anemia $\geq 40 \%$.

Laporan Riset kesehatan dasar (Riskesdas) tahun 2013 menunjukkan bahwa anemia defisiensi besi masih merupakan masalah kesehatan masyarakat Indonesia dengan prevalensi pada anak usia 5 - 12 tahun sebesar 29\% dan di Kota Makassar sebesar 37,6\%. Dampak anemia bagi siswa sekolah dasar adalah dapat menyebabkan gangguan tumbuh kembang fisik, rendahnya daya tahan terhadap penyakit, tingkat kecerdasan yang kurang dari seharusnya, prestasi belajar/kerja dan prestasi olahraga yang rendah. Selain itu, anemia pada anak akan berdampak pada menurunnya kemampuan dan konsentrasi belajar, mengganggu pertumbuhan baik sel tubuh maupun sel otak sehingga menimbulkan gejala muka tampak pucat, letih, lesu dan cepat lelah sehingga dapat menurunkan kebugaran dan prestasi belajar.

Anemia merupakan suatu keadaan ketika jumlah sel darah merah atau konsentrasi pengangkut oksigen dalam darah (Hemoglobin) tidak mencukupi untuk kebutuhan biologis tubuh. ${ }^{4}$ Anemia dipengaruhi oleh faktor ekstrinsik dan intrinsik. Faktor ekstrinsik yang mempengaruhi kejadian anemia, antara lain pengetahuan tentang gizi khususnya anemia, tingkat pendidikan orang tua, tingkat ekonomi, infeksi, dan kebiasaan hidup. Faktor intrinsik yang mempengaruhi kejadian anemia, antara lain kehilangan darah secara kronis, seperti pada penyakit ulkus peptikum, hemoroid, infeksi parasit (kecacingan), asupan zat besi yang kurang dan penyerapan yang tidak adekuat, peningkatan kebutuhan akan zat besi untuk pembentukan sel darah, yang berlangsung pada masa pertumbuhan bayi, masa pubertas, masa kehamilan dan menyusui. ${ }^{7}$ 
Anemia defisiensi besi dapat disebabkan oleh kurangnya asupan makanan yang mengandung zat besi dan konsumsi makanan penghambat penyerapan zat besi, serta penyakit infeksi. Selain itu, disebabkan oleh distribusi makanan yang tidak merata ke seluruh tubuh, serta pola makan yang kurang beragam turut menunjang kurangnya asupan zat besi bagi tubuh.

Anemia defisiensi besi dapat juga dipengaruhi oleh kebutuhan tubuh yang meningkat, akibat mengidap penyakit kronis, kehilangan darah karena menstruasi, dan infeksi parasit (cacing). Di Indonesia, penyakit kecacingan masih merupakan masalah yang besar untuk kasus anemia defisiensi besi karena diperkirakan cacing menghisap darah 2-100 cc setiap harinya.

Masyarakat Indonesia masih banyak yang belum membiasakan sarapan. Padahal dengan tidak sarapan akan berdampak buruk terhadap proses belajar di sekolah, menurunkan aktivitas fisik, dan meningkatkan risiko jajan yang tidak sehat. Melewatkan sarapan pagi menjadi isu kesehatan masyarakat di dunia. Salah satu cara untuk memberantas anemia pada siswa sekolah dasar adalah dengan membiasakan anak-anak sarapan untuk menjaga kesehatan dan meningkatkan perilaku anak di sekolah. Hanya 27,7\% dari orangtua siswa yang anaknya mengalami defisiensi besi menyadari bahwa sarapan dapat meningkatkan konsentrasi belajar di sekolah, sementara $22,4 \%$ dari orangtua siswa tidak tahu tentang pentingnya sarapan dan efeknya pada kesehatan anak.

\section{METODE PELAKSANAAN}

\subsection{Solusi dan Target Luaran}

Kegiatan ini sebagai kegiatan sosial untuk memberikan pengetahuan, pelatihan dan penanganan kepada seluruh anak usia sekolah dasar, tentang anemia meliputi pengertian, gejala, tanda pengobatan dan cara pencegahannya.

\subsection{Lokasi Kegiatan Pelaksanaan}

Waktu pelaksanaan tanggal 26 September 2020 di Madrasah Ibtidaiyah Fatthur Rahman Makassar.

\subsection{Metode Kegiatan}

Kegiatan pengabdian ini dilaksanakan oleh 2 orang dosen Fakultas Kedokteran Universitas Muslim Indonesia, 1 orang mahasiswa dan diikuti oleh 35 orang peserta, yaitu anak usia sekolah terutama kelas 4, kelas 5, dan kelas 6. Sebelum melakukan kegiatan, peserta melakukan registrasi terlebih dahulu. Kemudian peserta mengikuti presentasi dan diskusi yang dibawakan oleh dosen tentang anemia, bagaimana cara 
pencegahan anemia melalui upaya kebiasaan sarapan sehingga dapat terhindar dari anemia. Pada kegiatan ini juga dilakukan pemeriksaan kadar hemoglobin darah pada peserta.

\section{HASIL DAN PEMBAHASAN}

Kegiatan pengabdian kepada masyarakat ini berlangsung selama 9 minggu terhitung sejak persiapan kegiatan hingga pembuatan laporan akhir. Program inti kegiatan yakni Pelatihan Deteksi, Tata Laksana dan Pencegahan Anemia Pada Anak Usia Sekolah Dasar di Madrasah Ibtidaiyah Fatthur Rahman Makassar, yang berjarak $\pm 6,4 \mathrm{~km}$ dari Universitas Muslim Indonesia, dilaksanakan pada hari Sabtu tanggal 26 September 2020.

Kegiatan ini diikuti oleh siswa siswi Sekolah Dasar Madrasah Ibtidaiyah Fatthur Rahman Makassar sebanyak 35 orang peserta yang berasal dari kelas 4, kelas 5, dan kelas 6. Peserta terlihat sangat antusias selama kegiatan berlangsung. Hal ini terlihat dari banyaknya pertanyaan yang diajukan oleh peserta berkenaan dengan materi yang dipresentasikan. Sebelum mengikuti materi, peserta dibagikan leaflet sebagai bahan bacaan pengenalan tentang anemia, kemudian peserta diberikan penjelasan tentang anemia, lalu diadakan sesi diskusi, kemudian peserta diperiksakan kadar hemoglobinnya dengan cara mengambil sampel darah kapiler melalui metode POCT (Point Of Care Testing).

Hasil yang diperoleh setelah pelaksanaan kegiatan pengabdian ini adalah sebanyak $>90 \%$ anak usia sekolah dasar dapat mengetahui tentang anemia meliputi gejala, tanda, dan cara pencegahannya. Sebanyak $>90 \%$ anak usia sekolah dasar dapat menjaga perilaku sehat dengan membiasakan diri sarapan sebagai bentuk pencegahan dari anemia. Ditemukan satu anak usia sekolah dasar yang terkena anemia, dengan kadar hemoglobin 8,7 mg/dl. Anak usia sekolah dasar jika terkena anemia dapat sembuh tanpa adanya gejala sisa.

Kegiatan ditutup dengan penyerahan goodie bag yang berisikan susu, snack, dan alat tulis sebagai tindakan preventif dan hadiah kepada semua peserta kelas 4, kelas 5 dan kelas 6 , serta penyerahan Alat Timbangan Berat Badan, Alat Ukur Tinggi Badan, Anti Septik (Hand Sanitizer Gel) kepada Kepala Sekolah Madrasah Ibtidaiyah Fatthur Rahman Makassar.

Tabel 1. Hasil pengukuran kadar hemoglobin

\begin{tabular}{|c|c|c|c|c|c|c|c|}
\hline NO & NAMA & KELAS & $\begin{array}{c}\text { UMUR } \\
(\text { TAHUN) }\end{array}$ & $\begin{array}{c}\text { JENIS } \\
\text { KELAMIN }\end{array}$ & $\begin{array}{c}\text { BERAT BADAN } \\
(\mathrm{Kg})\end{array}$ & $\begin{array}{c}\text { TINGGI } \\
\text { BADAN }(\mathrm{Cm})\end{array}$ & $\begin{array}{c}\text { HEMOGLOBIN } \\
(\mathrm{g} / \mathrm{dL})\end{array}$ \\
\hline 1 & $\mathrm{HD}$ & 6 & 11 & $\mathrm{P}$ & 30 & 137,5 & 15 \\
\hline 2 & $\mathrm{MJ}$ & 6 & 11 & $\mathrm{P}$ & 41 & 152 & 15,4 \\
\hline 3 & $\mathrm{AR}$ & 6 & 11 & $\mathrm{P}$ & 37 & 153 & 14,3 \\
\hline 4 & $\mathrm{MN}$ & 6 & 11 & $\mathrm{P}$ & 40 & 154 & 13,1 \\
\hline
\end{tabular}


Jurnal Pengabdian Kedokteran Indonesia, Vol.2 No.1 (Maret, 2021); e-ISSN 2745-4495

\begin{tabular}{|c|c|c|c|c|c|c|c|}
\hline 5 & SM & 6 & 11 & P & 26 & 139 & 14,8 \\
\hline 6 & MA & 6 & 12 & L & 25 & 132 & 13,3 \\
\hline 7 & NV & 6 & 10 & P & 25 & 132 & 13,4 \\
\hline 8 & APR & 6 & 10 & L & 23 & 128 & 13 \\
\hline 9 & SR & 6 & 12 & P & 31 & 143 & 12,6 \\
\hline 10 & IAN & 6 & 11 & P & 35 & 143 & 13,7 \\
\hline 11 & SM & 6 & 13 & P & 32 & 147 & 15,8 \\
\hline 12 & RF & 6 & 11 & L & 28 & 144,5 & 13,7 \\
\hline 13 & AA & 6 & 11 & L & 29 & 133 & 15,8 \\
\hline 14 & EPI & 6 & 11 & P & 37 & 145,5 & 18,1 \\
\hline 15 & RS & 6 & 11 & P & 29 & 142 & 13,1 \\
\hline 16 & FM & 5 & 10 & L & 65 & 154 & 14,6 \\
\hline 17 & MF & 4 & 8 & L & 24 & 131 & 14,5 \\
\hline 18 & DZ & 4 & 10 & L & 23 & 134 & 13,7 \\
\hline 19 & SR & 4 & 9 & P & 24 & 124 & 13 \\
\hline 20 & NJ & 4 & 10 & P & 23 & 125 & 14,4 \\
\hline 21 & MH & 6 & 11 & P & 31 & 141 & 13,8 \\
\hline 22 & MR & 6 & 11 & L & 28 & 140,5 & 17,1 \\
\hline 23 & FAF & 5 & 9 & L & 22 & 125 & 13,4 \\
\hline 24 & SV & 5 & 9 & P & 25 & 129,5 & 13,8 \\
\hline 25 & AP & 4 & 9 & L & 25 & 131 & 15,9 \\
\hline 26 & AK & 4 & 8 & L & 19 & 118 & 10,3 \\
\hline 27 & ST & 4 & 8 & L & 21 & 123 & 11,4 \\
\hline 28 & NS & 5 & 9 & P & 20 & 123 & 13,7 \\
\hline 29 & MS & 5 & 12 & L & 25 & 129 & 13,6 \\
\hline 30 & MR & 4 & 9 & L & 21 & 124 & 8,7 \\
\hline 31 & KR & 6 & 12 & P & 35 & 145 & 12,7 \\
\hline 32 & NA & 6 & 12 & P & 35 & 140 & 12,6 \\
\hline 33 & ZF & 6 & 11 & P & 29 & 145 & 13,7 \\
\hline 34 & RJ & 6 & 11 & P & 32 & 143 & 12,6 \\
\hline 35 & HR & 6 & 12 & P & 31 & 145 & 14,7 \\
\hline
\end{tabular}
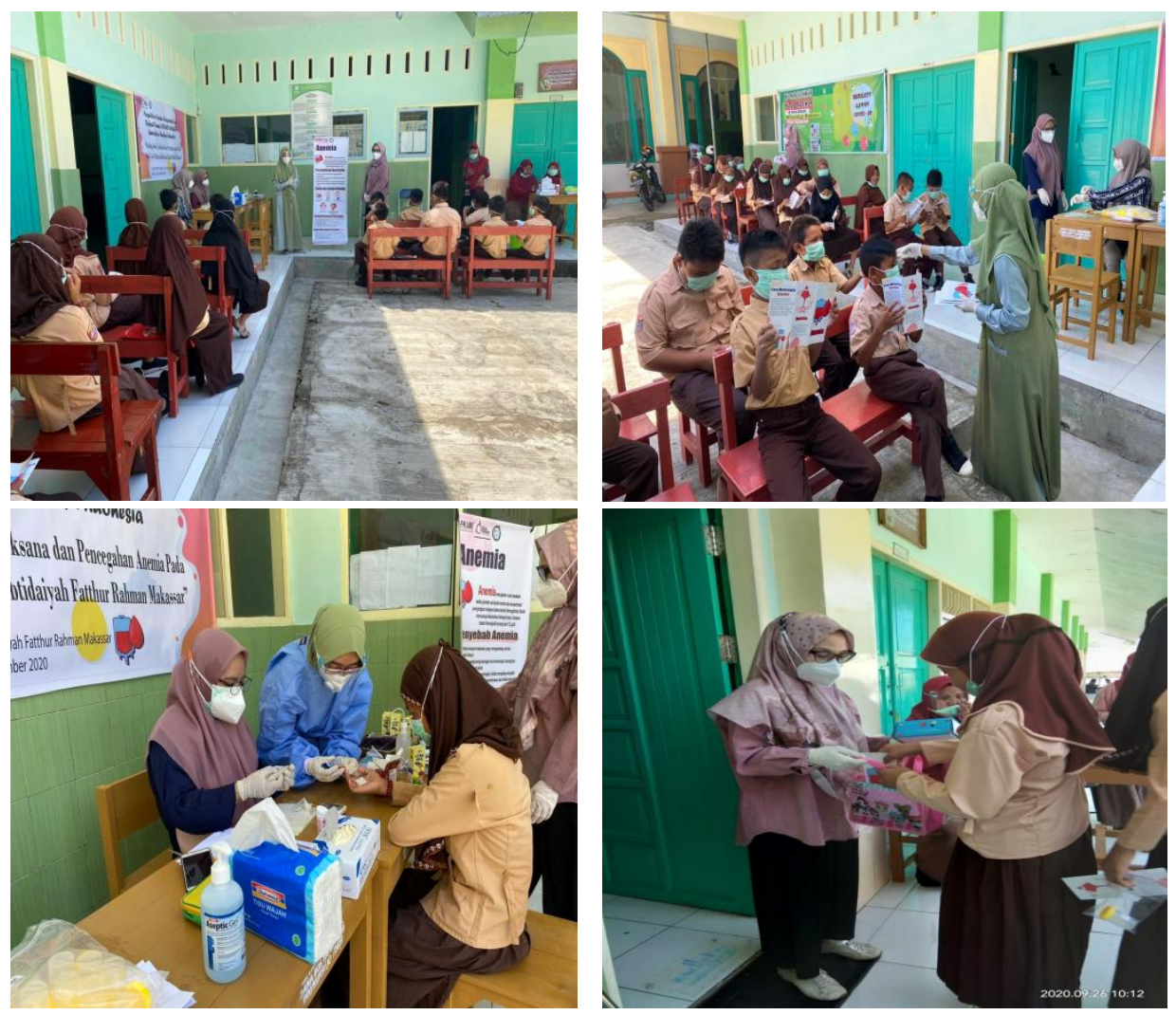

Gambar 1. Dokumentasi Kegiatan Pelatihan Deteksi, Tatalaksana Dan Pencegahan Anemia Anak Usia Sekolah Di Madrasah Ibtidaiyah Fatthur Rahman Makassar 


\section{KESIMPULAN DAN SARAN}

Hasil dari kegiatan pelatihan, tata laksana dan pencegahan anemia ini dapat disimpulkan bahwa anak usia sekolah dasar telah mengetahui tentang anemia yang meliputi pengertian, tanda, gejala, dan bagaimana cara pencegahan anemia. Mereka juga mampu berperilaku hidup sehat dengan membiasakan diri sarapan sebagai salah satu upaya untuk mencegah terjadinya anemia pada anak usia sekolah dasar.

Kegiatan pengabdian kepada masyarakat seperti ini alangkah baiknya jika dilaksanakan secara rutin di lokasi yang berbeda, sehingga semua anak usia sekolah dasar dapat terhindar dari anemia. Untuk selanjutnya dapat pula dilengkapi dengan memberikan kuesioner tentang sikap dan pengetahuan anak tentang anemia dan dampak dari anemia, serta melakukan pemeriksaan kadar hemoglobin kembali setelah enam atau dua belas bulan kemudian.

\section{Ucapan Terima Kasih}

Dekan Fakultas Kedokteran Universitas Muslim Indonesia, Ketua LPMD-UMI yang telah memberikan bantuan dana kepada kami, Kepala Sekolah Madrasah Ibtidaiyah Fatthur Rahman Makassar yang telah memberikan ijin kepada kami untuk melakukan kegiaan pengabdian masyarakat ini, dan semua pihak yang tidak dapat kami sebutkan satu persatu namanya yang telah membantu terlaksananya kegiatan ini.

\section{DAFTAR PUSTAKA}

1. WHO. Worldwide prevalence of anemia 1993 - 2005, WHO global database on anaemia. Geneva: WHO library cataloguing-in-publication data; 2008.

2. Arisman. Gizi dalam daur kehidupan. Jakarta: Penerbit Buku Kedokteran EGC; 2010.

3. Khomsan. Ekologi masalah gizi, pangan dan kemiskinan. Bandung: Alfabeta; 2012.

4. Riskesdas. Riset kesehatan dasar. Jakarta. Badan Penelitian dan Pengembangan Kesehatan Kementerian Kesehatan RI. 2013.

5. Kementerian Kesehatan Republik Indonesia. Riset kesehatan dasar (Riskesdas) tahun 2013. Jakarta: Badan Penelitian dan Pengembangan Kesehatan Kementerian Kesehatan Republik Indonesia; 2013.

6. Nirmala D. Gizi anak sekolah. Jakarta: Penerbit Buku Kompas; 2012.

7. Dewi M, Sutiari K, Wulandari L. Status anemia gizi besi dan konsumsi zat gizi pada anak usia sekolah di lima panti asuhan di kota denpasar. Arc. Com. Health; 2012.

8. Cakrawati D, Mustika NH. Bahan pangan gizi dan kesehatan. Bandung: Alfabeta; 2012.

9. Proverawati A, Misaroh. Manarche. Yogyakarta: Muha Medika; 2009.

10. Kementerian Kesehatan Republik Indonesia. Pedoman gizi seimbang. Jakarta: Dir ektorat Jenderal Bina Gizi dan KIA; 2014. 